\title{
PROPERTY MANAGEMENT OF AFFORDABLE HOUSING: A RESILIENCE PERSPECTIVE
}

\author{
XIAOLIN LAO \\ Huazhong University of Science and Technology, China
}

ABSTRACT

The COVID-19 incident has forced us to think carefully about the vulnerabilities in the city's public administration and to prepare for future risks. In China, urban and rural communities are the basic units of social governance. Affordable housing is a category of social housing provided by the Chinese government for the benefit of low-income urban families, and its property management services often suffer from insufficient funding sources, thus aggravating the problem of supplying its property services. Therefore, faced with risks, the vulnerability of this type of community is more pronounced than that of normal communities, so its property management resilience should be given high priority. Property management is a part of community governance. From a resilience standpoint, in normal time, it should not only deal with securing the supply of property services, formulating emergency measures, strengthening the stock of emergency supplies, and improving the maintenance of emergency facilities; in crisis, but it should also deal with the deployment of emergency supplies, emergency operation of public utilities, and enhancing the maintenance of emergency facilities. This paper aims to clarify the rights, responsibilities, and public nature of affordable housing, analyze the functions that each entity should play in property management services, and then explore solutions to the misalignment of rights and responsibilities in its property services, thus increasing property resilience in community governance and improving community resilience.

Keywords: affordable housing, property management, resilience, public goods.

\section{INTRODUCTION}

China's housing system is based on five pillars: housing finance, land, taxation, housing indemnification and housing supply. The indemnification housing system is divided into affordable housing, low-rent house, and public rental housing.

The marketisation process of Chinese society has witnessed the withdrawal of the Danwei system from the historical stage. Following the Danwei housing, the implementation of the affordable housing system has once again made housing a form of social welfare. On the one hand, it guarantees their fundamental right for living, but on the other hand, the unconscious "expansion of rights," due to these protected groups' misconception of the policy, has made affordable housing encounter an unprecedented institutional dilemma. Based on the system origin and property ownership model of affordable housing in China, this paper provides an insightful analysis of the rights and obligations of affordable housing stakeholders. The case study of Beijing's Yulong Mingju clarifies the dilemma of the affordable housing system due to the misalignment of rights and obligations and proposes strategies for different interest groups to break through the dilemma from the perspective of resilience.

The impetus for future innovation in the affordable housing system will inevitably have to come from the healthy interaction between the government, property management enterprises, property management associations and property users in the process of practice. The ultimate goal of indemnification housing is to meet the housing needs of vulnerable groups, which are often diversified and multi-layered. It isn't easy to fully achieve this goal through purely intergovernmental administrative directives and must be accompanied by 
innovative and locally adapted government working methods, the regulation of industrial standards and the increased participation of residents' self-government.

\section{RESILIENCE OF PROPERTY MANAGEMENT}

The term "resilience" is derived from the Latin word "resilio," which was first proposed by the Canadian ecologist Holling, who argued that the behaviour of ecosystems could be defined by two different attributes, namely resilience and stability, and distinguished between engineering resilience and ecological resilience [1]. The meaning of resilience refers to a system exposed to disaster/risk maintaining its basic structure and function through effective resistance, absorption, and adaptation to the risk, and recovering from the disaster. As the concept of resilience continues to evolve, while there are different definitions of resilience, some commonalities exist: namely, an emphasis on resilience's ability to adapt to changes in the external environment and to learn from disasters, as well as the system's multiple equilibria and self-organisation.

A United States Commercial Real Estate Services (CBRE) study on "Resilience and Property Management" concludes that property managers need to develop resilient property management strategies in advance to withstand unexpected risks, which include accurately assessing the safety hazards of their properties and developing comprehensive disaster plans and measures [2].

\section{AFFORDABLE HOUSING SYSTEMS AND MODELS IN CHINA}

The public (social) housing system guarantee is provided by the government for middleand low-income families. It is of a social welfare nature. China's existing indemnification housing system is divided into three categories: affordable housing, low-rent house, and public rental housing.

\subsection{Affordable housing system in China (see Table 1)}

In June 1991, the Notice of the State Council on Continuing the Reform of the Urban Housing System in a Positive and Prudent Manner (No. 30 [1991], State Council), which for the first time introduced a concept similar to that of "affordable housing," making it clear that housing could be not only commercial but also indemnification. In the Decision on Deepening the Reform of the Urban Housing System (No. 43 [1994] of the State Council) of the State Council in July 1994, "affordable housing" was first explicitly introduced in a policy document. Notice of the Ministry of Construction, the National Development and Reform Commission, the Ministry of Supervision, the Ministry of Finance, the Ministry of Land and Resources, the People's Bank of China and the General Administration of Taxation on Issuing the Administrative Measures for Affordable Houses (No. 258 [2007] of the Ministry of Construction), regulating the construction costs, funding sources and supply standards of affordable housing, which marks the initial formation of China's affordable housing system [3]. The Circular of the State Council on Further Deepening the Urban Housing System Reform and Accelerating Housing Construction (No. 23 [1998] of the State Council) marks the formal integration of affordable housing into China's indemnification housing system [4]. 


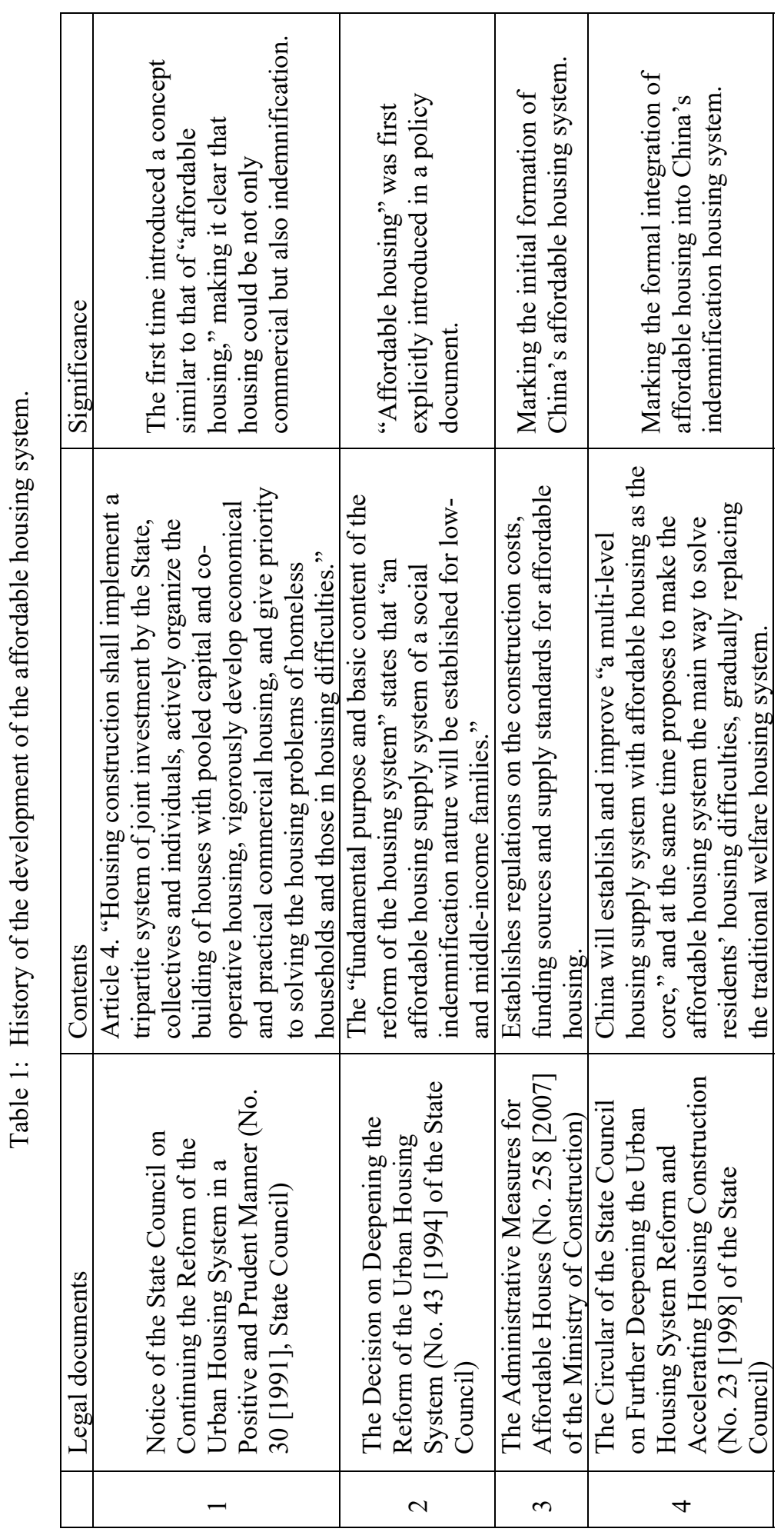




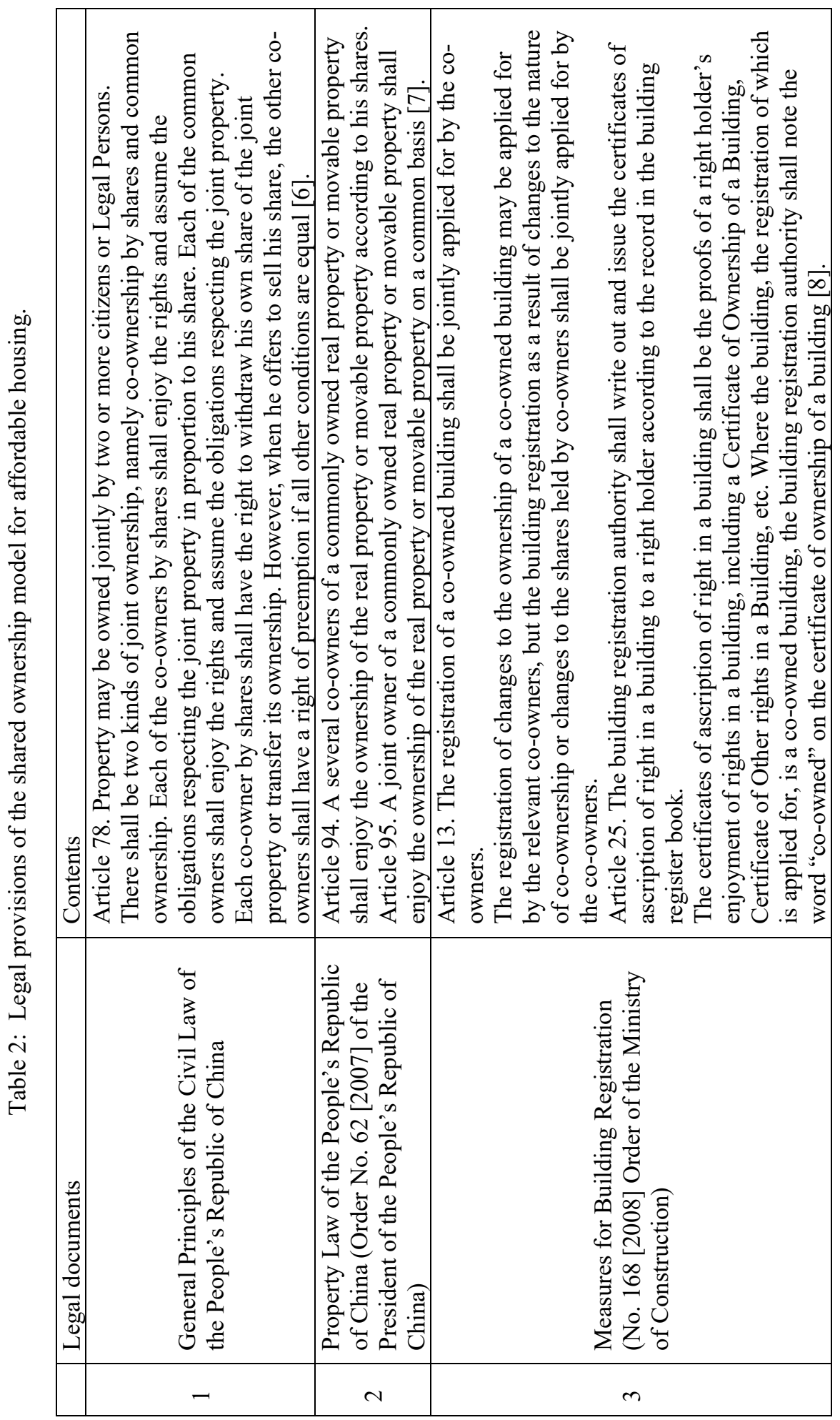




\subsection{Legal provisions of the shared ownership model for affordable housing}

Shared ownership is a property rights system arrangement in which the costs and benefits are shared between exclusive groups. Shared ownership housing (see Table 2), in short, means that families with low-to-moderate income housing difficulties who cannot afford to buy a home in a lump sum can jointly own the property rights of that home in proportion to their individual and government contributions [5]. Current international shared ownership housing policies include shared ownership housing and shared equity housing in the UK, and community land trusts housing and limited equity cooperatives housing in the US, and co-ownership housing in Australia.

\subsection{Qualification of affordable housing purchasers}

Notice of the Ministry of Construction, the National Development and Reform Commission, the Ministry of Supervision, the Ministry of Finance, the Ministry of Land and Resources, the People's Bank of China and the General Administration of Taxation on Issuing the Administrative Measures for Affordable Houses (No. 258 [2007] of the Ministry of Construction), Article 25 to apply for purchasing an affordable house, an urban low-income family shall simultaneously satisfy the following requirements:

1. It has registered permanent residence in the city or town where the house is located;

2. Its household income is below the low-income family line as determined by the municipal or county people's government; and

3. It has no house or the currently dwelling space satisfies the housing difficulty standards as determined by the municipal or county people's government.

\section{RIGHTS AND OBLIGATIONS OF AFFORDABLE HOUSING AND ITS PUBLIC NATURE}

The perception of residents' rights in relation to housing is based on the formation of housing ownership. With the implementation of the affordable housing policy, the government has assumed residential responsibility for those unable to afford commercial housing. At the same time, these groups are given the basic right to occupy social housing. However, these groups that were sheltered believe that these housings are governmentowned and are public goods for which the government should be responsible. So, they believe they are not obliged to pay the property management fees, causing many conflicts after they live.

Residents who do not pay property management fees or who believe that the government should take over property management are "expanding rights" after basic rights have been fulfilled. First, a new relationship of dependency has been established between affordable housing dwellers and the government when those were granted access to affordable housing and was the underlying motivation for "expanding rights" of affordable housing dwellers. Secondly, affordable housing residents' claim for "expanded rights" requires the conditions for its triggering and its legitimacy. The newly established status of "affordable housing dwellers," characterizing the symbol of "vulnerable groups," is a factor of legitimacy that allows the demand for "expanded rights" to take place. In other words, under the political discourse of safeguarding and improving people's livelihoods, “ vulnerable group" shapes the "legitimacy" of the action of "expanding rights." Thirdly, the spatial aggregation of vulnerable groups has become an organizational condition for forming the demand for the "extension of rights." 
Affordable housing dwellers with similar lower economic conditions have been gathered together into the community from all around the city. That kind of spatial concentration stimulated dwellers to a certain degree of "right consciousness," thus creating the motivation, desire, and requirements to claim "expanding rights." In a word, affordable housing dwellers use not only their identity symbols but also the concentrated spatial community shapes "expanding rights."

\subsection{Rights and obligations of affordable housing under the shared ownership model}

\subsubsection{Rights}

1. Possession and use rights

Affordable housing owners have the right to occupy and use the housing with restrictions. This is reflected in the fact that they are not allowed to destroy the function of the housing, rent out the housing without permission and other acts that do not comply with the regulations of the affordable housing with shared ownership.

\section{Income rights}

Affordable housing with shared ownership model is available for trading in the market after certain conditions are met. Affordable housing in Beijing is co-ownership by shares, which entitles the co-owners to share the housing proceeds. It is important to note that affordable housing under this model does not give the owners the right to rent, and accordingly, the government does not have the right to rent affordable housing, and the government is not allowed to charge the owners rent.

\section{Alteration and repair rights}

There is no right to alteration or repair of the home for those owners. Property Law of the People's Republic of China, stipulated that the reconstruction or alteration of a buildings and its appurtenant facilities requires the consent of the owners whose exclusive part accounts for more than two-thirds of the floor area and at least two-thirds of the total number of owners. However, under China's existing ownership proportion arrangement for affordable housing, which is generally $30 / 70$ or 50/50, almost one-third of the housing ownership will be enjoyed by the government, regardless of the ownership proportion arrangement in which the protector is placed, which means that if the government does not agree to make alterations or repairs to the housing, then the alterations and repairs to the housing cannot be carried out.

\subsubsection{Obligations}

\section{Home maintenance obligations}

The government and the protected person shall share the maintenance costs of affordable housing under shared ownership in proportion to their own contributions. Article 98 of the Property Law stipulates that all or some of the co-owners shall share in the maintenance and repair costs of the house in accordance with their share of the capital contribution.

Article 98. As for the management expenses or any other liabilities of a commonly owned property, if there is any stipulation on it, such stipulation shall apply; if there isn't any stipulation on it or the stipulation is not clear, the expenses shall be borne by the several co-owners on the basis of their respective shares or commonly borne by all joint owners. 


\section{Property management fees paying obligations}

Property services include greening, sanitation, maintenance, and repair of houses and ancillary facilities in the community. The property management fee is a daily fee paid by the owner or the actual user of the property to the entrusted property management agency, based on the occupation and use of the house.

Under the shared ownership model, the government is in a special position and is not obliged to bear the cost of property management. The government should not be jointly and severally liable for the payment of property management fees by other co-owners to avoid being caught in civil disputes and being a passive subject of liability. Meanwhile, the owners' ownership percentage does not affect their house use, as the government has ceded the right to use the house to the owners. Because of the nature and use of the property management fees, the actual occupier of the house, i.e. the owners, should be obliged to pay the full cost of the property.

\subsection{The public nature of affordable housing and its property management services}

\subsubsection{Property management services of affordable housing are partially excludable and non-competitive}

The counterpart of public goods is private goods. Samuelson divides goods into purely public and purely private goods, and he argues that public goods have significant nonexclusive and non-competitive characteristics in relation to private goods [9].

Quasi-public goods have limited non-competitive and partial excludable, as well as externalities and natural monopolies, and are social goods between private goods and pure public goods [10]. Quasi-public goods are divided into two categories: those with a nonexclusive and competitive character, i.e., common-pool resources, and those with an exclusive and non-competitive character, i.e., club goods (artificially scarce goods). Quasipublic goods are generally congested, i.e., when the number of consumers increases to a certain threshold, there is a positive marginal cost, unlike pure public goods where the marginal cost is zero for each additional person. When a quasi-public good reaches a "limited capacity," each additional person will reduce the utility of the initial consumer.

Does affordable housing, as a type of indemnification housing, have the attributes of a quasi-public good? The answer is yes.

Firstly, the land used for affordable housing is allocated by the State to developers for free and is built without profit. The selling price is considered by the municipal and county people's governments according to the cost price and is guided by the government. Secondly, unlike public rental housing and low-rent housing, the ownership rights of which belong entirely to the government are of a strong public nature. Affordable housing is a project that government initiative to solve the housing problems of the middle and lowerincome groups and to offer part or all of the ownership rights to these groups at a price lower than the market. Hence, some of the affordable housing is fully self-owned, and some is jointly owned by the homeowner and the government. As its ownership is not fully occupied by a single household, it cannot be used as a property investment asset. Thirdly, the supply of affordable housing is aimed at the majority of the low and middle-income groups but not fully covered, so it has a partially excludable. Fourthly, the allocation process for affordable housing is a vetting system, and access is non-competitive as long as income conditions are met. On the other hand, people who do not belong to these groups cannot qualify for access, and such exclusivity is a club good. However, the quantity of affordable housing in China is currently limited. The supply is less than the demand, and the marginal cost of increasing the number of consumers is positive and congested. In other 
words, affordable housing is competitive within the club of "low and middle-income groups." In summary, affordable housing is a quasi-public good with limited noncompetitiveness and is partially exclusive.

\subsubsection{Property management services of affordable housing are partially excludable and non-competitive}

The nature of affordable housing determines the public or quasi-public product nature of its later property management. This is because, on the one hand, affordable housing property management serves that are partially or fully owned by the government; on the other hand, it serves low- and middle-income people in towns and cities who are most in need of care and who do not have sufficient payment capacity to purchase property services on the market.

Affordable housing property services are aimed at owners of affordable housing residents, so it has an exclusive feature. Still, owners of affordable housing communities can enjoy property services simply by paying below the market rate. Moreover, in general, within a certain range, an additional owner's property consumption does not bring an increase in cost to the property company, and the marginal cost is zero, which has the characteristic of non-competition.

\subsubsection{Efficiency losses of affordable housing property management services}

Affordable housing services are non-excludable in terms of consumption, and most people have a "free-rider" mentality, hoping that others will bear the costs. To provide this entirely through market mechanisms would lead to inefficient allocation of resources.

\section{CASE STUDY: YULONG MINGJU COMMUNITY IN HUAIROU DISTRICT, BEIJING}

Beijing began building affordable housing in 1998 and has been applying the limited shared ownership model.

Measures for the Administration of Affordable Housing in Beijing (No. 27 [2007] Order of the People's Government of Beijing Municipality) stipulated that affordable housing cannot be listed and traded for five years, and full ownership can be acquired after five years. Beijing municipal commission of housing and urban-rural development the Notice on Issues Relating to the Listing and Sale of Purchased Affordable Housing (No. 225 [2008] Order of Beijing municipal commission of housing and urban-rural development), stipulated the steps for the sale of affordable housing after five years and the distribution of proceeds.

The beneficiary acquires affordable housing ownership in the limited shared ownership model through payment of the housing price. However, the right to transfer and dispose of the property is restricted. The housing cannot be traded for five years after purchase and can only be repurchased by the government at a price determined by considering the purchase price and other discount factors. After five years of purchase, the recipient acquires full rights to the property, subject to taxes and land premiums. In this model, the ownership of the house is granted exclusively to the person under protection. It mainly belongs to the building's differentiated ownership. The right to gain and dispose of the house is restricted and the circulation transfer can only be done in a particular scope by legal means.

The Yulong Mingju Community is an indemnification housing project in Huairou District in 2008, 97.5\% of the housing are affordable housing, located in the west of Chengezhuang Village, Yanqi Town, Huairou District, south of Zhonggao Road, covering 
an area of 5.97 hectares, with a construction area of 75,868 square metres and 9 storeys. The total number of households in the area is 978 , of which 954 are affordable housing and 24 are low-rent housing. The average size of the households is about 64 square metres. It is evident that this is a larger residential community and requires a professional property management company to take responsibility for the utilities, landscaping, hygiene, security, and environment. The construction of Yulong Mingju was financed by the government and the property management company was selected by the government's Housing and Urban Development Bureau after completion. The property management fees are lower than those of commercial properties and are basically based on market-based principles.

However, some residents could not agree with the fees and have had some friction with the property management company. So, since they moved in, it has been quite difficult for the property management company to charge. Quality of management is difficult to ensure due to low property funding. In response, the property management company has also reduced the level of property services. The owners' committee also failed to do an excellent job of communicating effectively between themselves in this process. Hence the vicious circle (Fig. 1), due to their dissatisfaction with the level of property services, residents are refusing to pay their property fees. In three years, close to $70 \%$ of the residents did not pay their property fees. Finally, the property management company withdrew from the community, and the property services are underpinning management by the government, which includes only the most basic waste removal. It can be seen that due to the lack of property management services, the community has long suffered from a lack of greenery, community safety concerns, poor quality of hygiene and environment, and unsecured infrastructure.

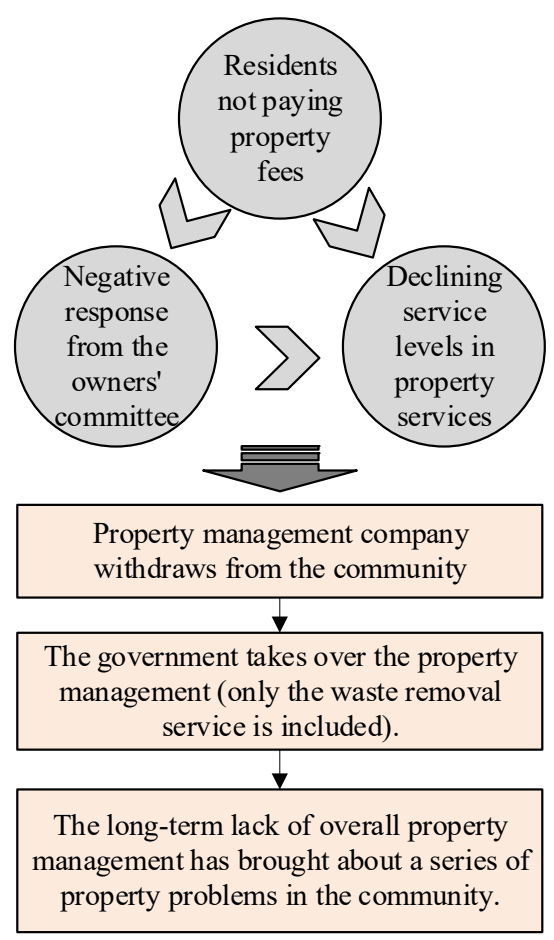

Figure 1: Vicious circle. 
Under the shared ownership model, residents own part of the affordable housing, enjoy the right to possession and use, and are responsible for part of the home maintenance costs and all property management fees (Fig. 2). When there is not the owners' committee in the community for self-governance, residents should pay their own property management fees on time under the property management company's rates. When a community has formed an owners' committee for self-governance, the committee should decide which approach the property management should take. The first is to choose to outsource all the property management services to a property management company; the second is for the owners' committee to organise residents to undertake the property management services themselves, charging only for the basic operation and damage of the facilities; and the third is to share the property management services with the property management company on a pro-rata basis, with the property management fees to be decided by the committee in consultation with the property management company. All three ways are charged by the owners' committee. Whether there is an owners' committee, the government is not obliged to undertake property management services in it.

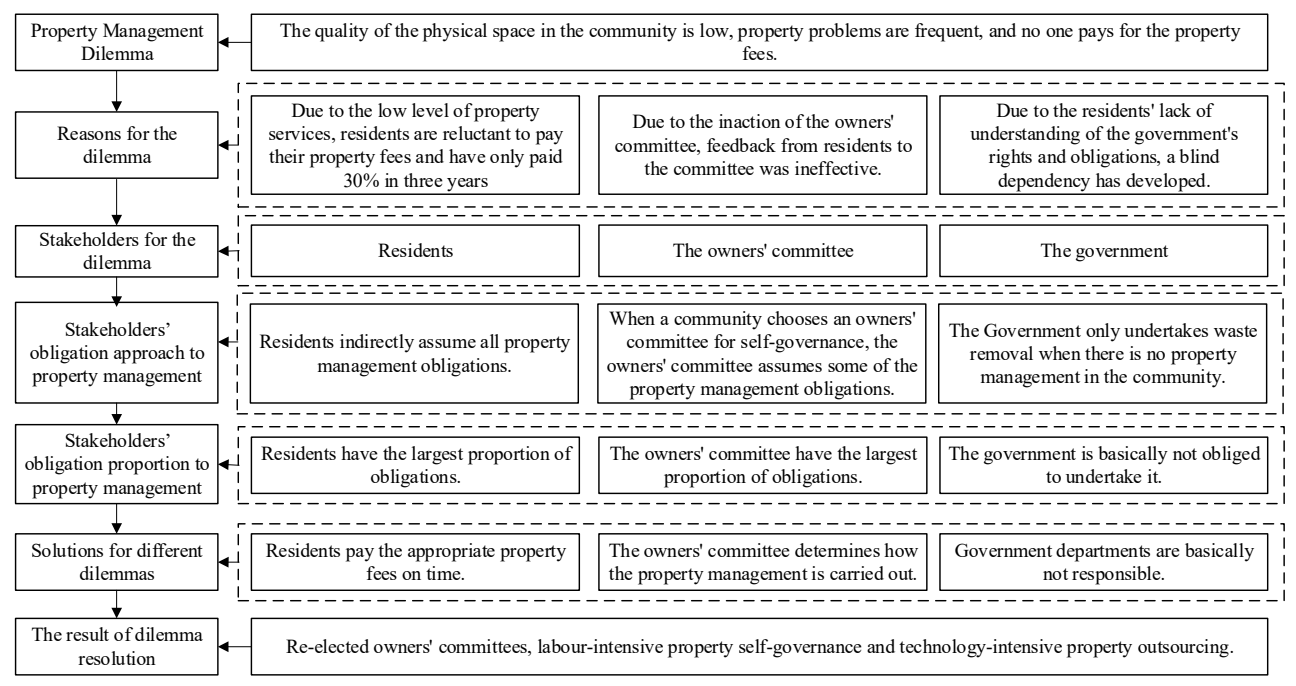

Figure 2: Processes of resolving property management.

\section{RESOLUTIONS OF MISALIGNED RIGHTS AND RESPONSIBILITIES OF AFFORDABLE HOUSING PROPERTY MANAGEMENT SERVICES FROM THE PERSPECTIVE OF RESILIENCE}

6.1 Government should safeguard financial resilience, awareness resilience and data resilience

1. Financial Resilience: The government gives financial support to affordable housing's management properties to ensure the daily operation.

Although the government is not obliged to bear the cost of property management, as affordable housing with the nature of public welfare and public goods, the property management of affordable housing has a strong positive externality, so it cannot rely 
entirely on the market operation. The government must give appropriate financial policy support to affordable housing properties to subsidise the negative externality losses caused to property companies by the government's price-limiting actions. For example, those enterprises that undertake property management services for affordable housing are given relevant tax relief, and the income tax and business tax rates of those enterprises are reduced; the income tax or business tax paid by property management enterprises for affordable housing is collected first and then returned proportionally.

2. Awareness resilience: The government clarifies the rights and obligations between the government and affordable housing residents through advocacy and education.

1) Resilience of rights and obligations in property management supply: The rights of affordable housing residents are totally dependent on the local government, and the identity of affordable housing residents becomes a tool and condition for them to claim their subsequent rights. Residents continue to demand property management services from the government because they have developed a onesided understanding of the rights and obligations relationship between themselves and the government, elevating their rights outside the framework of existing policies.

2) Risk Awareness Resilience: The government should strengthen the risk awareness of affordable housing residents through appropriate Party-building activities and news media advocacy tools. This includes raising risk awareness and conducting guidance and training on risk skills.

3. Data resilience: Government monitoring communities through big data platforms.

The infrastructure, population, and grid data of the affordable housing communities are shared with property management companies, community managers, community committees, and residents through big data visualisation guiding the decisions of the property management companies and community committees, and also raising residents' awareness of risk response in a relational manner.

\subsection{Property management companies should ensure physical space resilience} and property charging resilience during normal and emergency periods

Physical space resilience: Property management companies should conduct a comprehensive inspection and assessment of the security protection of existing properties before risks strike and upgrade or renew them as necessary to enhance their resilience, including the resilience of building performance, infrastructure, disaster prevention and mitigation spaces and facilities. For one, there are no private parking spaces as residents of affordable housing have low incomes. In this case, the property company should first survey the demand for parking spaces in the community, then make full use of the space to set up parking spaces, and guide residents to park in an orderly manner to improve the resilience of emergency access.

Property charging resilience: Property management enterprises and building manager committees, the Housing Authority signed a tripartite agreement to clarify the form and content of services, charges, etc., to enhance the resilience of property management, which enables evidence-based if disputes. Moreover, the cost of property services must not exceed $60 \%$ of the average property fee in general commercial housing communities, with the shortfall relying on financial subsidies and the profits of commercial operators to make up. 
6.3 Property management service recipients should raise awareness of rights and responsibilities and risk awareness

Awareness resilience of rights and responsibilities: Led by the street office, residents of each housing unit should elect a building manager, who forms a building management committee, which holds regular building manager meetings to discuss major issues regarding property management. The building managers' committee should establish a covenant for residents to help them shape a spirit of self-government and self-discipline and pay their property fees on time.

Risk Awareness Resilience: Residents should actively cooperate with the government and community committee on safety and disaster reduction education; consciously participate in risk-based skills training (including skills training on fire, earthquake, first aid, etc.); park vehicles in an orderly manner and maintain adequate escape life routes; consciously maintain community discipline and public space to enhance the resilience of disaster reduction and isolation space.

6.4 Property management associations should ensure the resilience of access and regulatory mechanisms

Access mechanism resilience: Property management association to assess the qualifications of property management companies being selected, setting property servicing standards by their actual situation, and enabling self-election to improve the access mechanism in property management.

Regulatory mechanism toughness: The Property Management Association improves the regulatory mechanism resilience, for example, after monitoring property users and property enterprises, enterprises that do not provide the corresponding services according to the contract after repeated warnings, revoking the qualification certificate and informing and criticising them; and giving criminal liability or informing and criticising property users who do not travel their obligations according to the contract.

Taking the first Community Environmental and Property Management Committee in Chengdu as an example, it was organised and established under the leadership of the Community Party Committee, recommended by the residents' representatives and set up under the Community Residents' Committee, mainly to do the coordinate work between property service companies and residents committees. It's not only to supervise the performance of the committees' duties, assist in convening residents' meetings, initiate residents' self-governance, but also to resolve conflicts. Finally, these means promoted the smooth development of property management, promoted residents' participation in property management affairs in an orderly and rational manner, and at the same time, realised community members participatory governance of self-management, self-education, self-service and self-monitoring.

\section{CONCLUSION}

In the initial stage of the affordable housing policy, the number of affordable housing was more important to meet the housing gap of the vulnerable groups. As their numbers increase and most of the housing-disadvantaged groups are provided with affordable housing, the importance of their numbers begins to diminish and the sustainability of affordable housing and the resilience of property management services becomes a key issue to be addressed at this stage. The property management dilemma in the Yulong Mingju community is indeed an unconscious "expansion of rights" due to the residents' confusion 
about their rights and obligations, which also reflects the shortcomings of the affordable housing policy and the lack of multi-stakeholder participation in the process of policy implementing.

Therefore, the resilience of property management in affordable housing must be led by the government, with the implementation of co-government and co-management among the government, property management enterprises, property users, and property management associations. In the practical application process, these tools need to be integrated and appropriately adjusted to the characteristics of different affordable housing communities, ultimately improving community resilience, safeguarding the lives of residents in times of normality and emergency, and improving their standard of living.

\section{REFERENCES}

[1] Holling, C.S., Resilience and stability of ecological systems. Annual Review of Ecology and Systematics, 4(1), pp. 1-23, 1973.

[2] CBRE, Global resilience and property management 2019. https://www.cbre.us/ research-and-reports/Global-Resilience-and-Property-Management--May-2019.

[3] Notice of the Ministry of Construction, the National. http://www.lawinfochina.com/ display.aspx?lib=law\&id=6533.

[4] Circular of the State Council on Promoting the Continuous. https://www.pkulaw.com/en_law/ae2c5e48e0447a9bbdfb.html.

[5] Wenlong, H. \& Chan, L., The origin, distribution and efficiency of shared ownership: An analysis based on the economics literature. Journal of Yunnan University of Finance and Economics, 2013(1), pp. 15-23, 2013.

[6] General Principles of the Civil Law of the People's Republic of China. http://english.court.gov.cn/2016-04/14/content_24530010_2.htm.

[7] Property Law of the People's Republic of China. http://english.www.gov.cn/services/ investment/23 Aug. 2014/content_281474982978047.htm.

[8] Measures for Building Registration. http://www.lawinfochina.com/display.aspx?lib= law\&id $=6728$.

[9] Samuelson, P.A., The pure theory of public expenditure. The Review of Economics and Statistics, 36(4), pp. 387-389, 1954.

[10] Barzel, Y., The market for a semipublic good: The case of the American economic review. The American Economic Review, 61(4), pp. 665-74, 1971. 